\title{
The benefits of development cage fish farming
}

\author{
Umida Sangirova ${ }^{1, *}$, Zulfiya Khafizova $^{1}$, Iskandar Yunusov ${ }^{1}$, Barna Rakhmankulova ${ }^{1}$, and \\ Umirzok Kholiyorov ${ }^{1}$ \\ ${ }^{1}$ Tashkent institute of irrigation and agricultural mechanization engineers, 39, Kari Niyazov \\ street, 100000, Toshkent, Uzbekistan
}

\begin{abstract}
The fishing industry has a special role in the development of the agricultural economy. Fish farming in cages is currently very important and is a promising and economically profitable form of growing marketable fish. The fishing industry has many advantages, such as beneficial effects on the health of the population, on the environment, and on the world's economy. Activities carried out in the fish farming industry provide ample opportunities. These activities are the organization of fish farming clusters, the use of intensive methods and resource-saving technologies, the transportation of compound feed and mineral fertilizers to fish farms. Intensive fish farming can reduce the cost of fish and maintain the existence of many types of commercial fish.
\end{abstract}

\section{Introduction}

Fish is the main source of protein, trace elements and other nutrients in the human diet. The value of fish lies in proteins, fat, vitamins, and even fish meal are obtained from fish. Doctors recommend eating fish up to 6-8 kilograms per year. Accordingly, the economic increase in the cultivation, processing and supply of fish products directly affects the improvement of human health.

In the Republic of Uzbekistan, fish such as sazan, carp, silver carp and catfish are mainly used. Medical experts have found that fish is useful for cardiovascular diseases, high blood cholesterol levels, anemia, chronic fatigue and various physical activities, neurosis, dermatological diseases, gout, rheumatism, decreased vision. [1]

According to world statistics, about 60 million people are employed in the field of fish farming in the world, and they account for about $9 \%$ of exports [2]. According to data for 2018, the volume of fish and seafood caught in the world amounted to 93.6 million tons. Fish is a popular, but at the same time perishable product, therefore special attention is paid to processing, preservation, packaging, storage and transportation of fish products. Different types and conditions of fish are popular in every part of the world. In Europe and North America, 2/3 of the fish consumed by the population is frozen or canned. In Africa and Asia, smoked and live fish are consumed respectively.

Fish farming has existed since ancient times, but fish farming has always received little attention, fishing and animal husbandry have developed much more actively. The development of fish farming is an acute issue not only in the Republic of Uzbekistan, but

\footnotetext{
* Corresponding author: indira91@inbox.ru
} 
all over the world. This issue is relevant, due to the fact that the natural reserves of waters, rivers, seas and oceans are decreasing, and it is necessary to turn to artificial water reserves [3].

Fish farming is not only a profitable industry, but also an industry of great social importance; the state introduces subsidies and benefits for entrepreneurs associated with this industry.

The fishing industry takes a special place in the food security of the Republic of Uzbekistan and the world as a whole. The share of the fish farming industry in the structure of the economy is increasing from year to year, and all this is due to the special attention from the state.

The fishing industry is an important component in the development of agriculture in the world. The Republic of Uzbekistan has natural water resources in the form of ponds, reservoirs, lakes, rivers, irrigation canals and others. But despite the rich water resources, the fish catch remains low. With regard to the consumption of fish products, less than 0.5 $\mathrm{kg}$ per capita per year. This figure is very low, since in order to maintain a healthy lifestyle, it is necessary to consume $10-12 \mathrm{~kg}$ per capita.

The problem of the fishing industry of the Republic of Uzbekistan is the production of fish seed and the irrational use of natural reservoirs and artificial ponds. The irrational use of these resources does not exceed 20 centners per hectare, this figure is the lowest among the world.

More than 4,000 fish farms function in the Republic of Uzbekistan; the total area of reservoirs engaged in fish farming exceeds 595 thousand hectares.

On the territory of the Republic of Uzbekistan, two groups of water bodies, the Amu Darya delta and the Aydar-Arnasay system of lakes, are of particular interest to fishermen.

The Republic of Uzbekistan mainly imports fish products (Tab.1).

Table 1. Countries of importers and exporters of fish products in the Republic of Uzbekistan.

\begin{tabular}{|l|c|l|}
\hline \multicolumn{1}{|c|}{ Type of product } & \multicolumn{1}{|c|}{ Export } & \multicolumn{1}{|c|}{ Import } \\
\hline Chilled type of fish & Afghanistan, Singapore & Russia, Turkey \\
\hline Frozen fish & - & $\begin{array}{l}\text { Norway, Russia, United Arab } \\
\text { Emirates, United Kingdom }\end{array}$ \\
\hline $\begin{array}{l}\text { Dried and smoked } \\
\text { fish }\end{array}$ & - & $\begin{array}{l}\text { Korea, Norway, Russia, Latvia, } \\
\text { Turkmenistan }\end{array}$ \\
\hline Canned food & $\begin{array}{l}\text { Belgium, Canada, Germany, } \\
\text { Italy, Latvia, USA, Turkey, } \\
\text { Russia, New Zealand, United } \\
\text { Arab Emirates }\end{array}$ \\
\hline
\end{tabular}

In fish farming projects, insufficient attention is paid to the financial and economic side of the management of this industry, especially in matters of justifying the choice of financing objects. The objects of funding are local, regional fish farming clusters [4].

Fish farming is actively developing in several districts with the participation of scientific institutions, where plans for the development of the industry are being formed and a line of integrated development of reservoirs is being formed. The Republic of Uzbekistan has favorable conditions for successful commercial fish farming.

In 2019, 200 thousand tons of fish were produced on the territory of the Republic of Uzbekistan. For 2020, it was planned to increase the volume of fish production to a minimum level of 350 thousand tons. Intensive fish farming may be the main driver of increased fish production, but it is not widely used. There are 38 thousand hectares of artificial reservoirs in the Republic of Uzbekistan, of which 242 hectares $(0.6 \%)$ are developing intensive fish farming.

To stimulate intensive fish farming, differentiated land tax rates are being introduced and they depend on the efficiency of the use of artificial reservoirs, and a subsidy is 
organized in the amount of 1 million soums for 1 ton of fish that has been raised by the intensive method. In each region of the Republic of Uzbekistan, one district will focus on fish farming. It is planned to allocate special loans for the creation of 10-15 intensive fish farms and 1 processing enterprise.

\section{Methodology}

Scientific substantiation of the development of the fishing industry has an important priority. The lack of a scientific approach limits the possibilities for fish farming, and leads to a decrease in production capacity [5].

The fishing industry is an interesting and deeply unexplored research topic. Intensive fish farming is considered in the context of the economic development of the country and the world as a whole. In the study of this topic, methods of analysis, synthesis, deduction, grouping, case method, and many other methods were applied. Theoretical methods are taken as the basis of research, since in order to apply empirical methods, it is necessary to conduct a detailed study and wait a certain period. In our subsequent works, it is planned to study in detail the practical side of the development of intensive fish farming both on the territory of the Republic of Uzbekistan and in the world as a whole.

\section{Result}

In the fishing industry, the operating principles must be followed. Industry monitoring is one such principle. Monitoring of the aquatic industry is carried out at least once a year; it is a systematic assessment of activities to determine effective directions. The production of marketable fish has its own characteristics (Fig.1).

\begin{tabular}{|c|c|}
\hline 1. Seasonality of production & $\begin{array}{l}\text {-The prime cost is determined at the end of the year, } \\
\text { since the fishing season lasts } 4-5 \text { months a year }\end{array}$ \\
\hline 2. Mismatch of periods & $\begin{array}{l}\text {-Water management costs last for a whole year, although } \\
\text { the production time lasts only } 4-5 \text { months }\end{array}$ \\
\hline 3. Special packaging & $\begin{array}{l}\text {-Finished products are sold in live form, so a special } \\
\text { container is required for transportation }\end{array}$ \\
\hline 4. Perishable product & $\begin{array}{l}\text {-Fish is a perishable product, a special container is } \\
\text { required for storing both live and finished products } \\
\text { (cold rooms, refrigerators) }\end{array}$ \\
\hline 5. Territorial stability & $\begin{array}{l}\text { - Reservoirs are not portable, so the means of production } \\
\text { should be as mobile as possible }\end{array}$ \\
\hline 6. Influence of climatic conditions & $\begin{array}{l}\text {-The amount of fish caught directly depends on the } \\
\text { natural and climatic conditions }\end{array}$ \\
\hline
\end{tabular}

Fig. 1. Features of the development of commercial fish production.

The state fully supports the development of the fishing industry. According to the Decree of President Sh.M. Mirziev "On measures to improve the management system of the fishing industry" of May 1, 2017, new opportunities are being created for the sphere. In accordance with this resolution, the Uzbekbaliksanoat association was established. In the regions of the Republic of Uzbekistan, the activities of about 13 territorial limited liability companies "Baliksanoat" were launched, they were exempted from the payment of a single 
tax payment in terms of income received from the production of commercial fish fry until January 1, 2023.

The most popular country for the export of the country is Vietnam, it ranks almost third in the world. Vietnamese technology implies the intensive rearing of fingerlings and their dynamic launch into reservoirs. In their technology, the consumption of compound feed is lower in comparison with the rate of development of fish, and resistance to negative waterchemical reactions and diseases is increased. If we use Vietnamese fish farming technology, then the fish catch from 20 centners can increase to 400 centners. Thanks to its technology, Vietnam holds $50 \%$ of the fish market with its catfish [6].

Science and practice moves alongside innovation. As you know, the traditional form of fish farming development is limited to land and water resources. Those who want to grow marketable fish are growing every day, but there are few reservoirs and ponds suitable for this. The way out of this situation is to create cages.

Cage fish farming is a new biotechnology in the aquaculture world, a development for the integrated use of water. The cages allow the development of new types of water bodies.

The beds are created in large ponds, reservoirs and even small rivers with a favorable hydro-chemical regime. In such places, cage farms are organized, which can consist of 2 or more cages for the production of marketable fish. The size of cage farms varies from small family holdings to large commercial establishments [7].

Gardens are arbitrary, but often they are rectangular or trapezoidal "bags" that hang freely directly into the water, consisting of a net (fig.2).

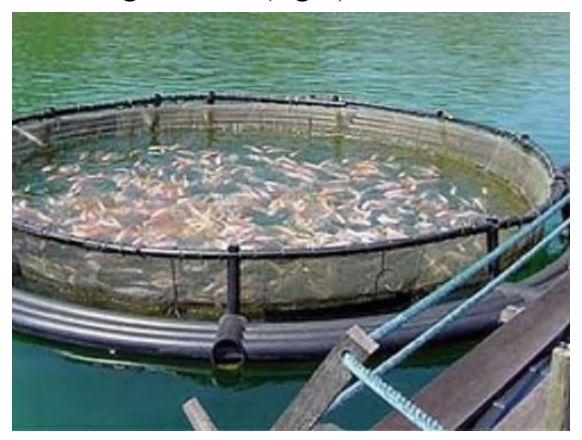

Fig. 2. Fish cages.

Intensive fish farming in the territory of the Republic of Uzbekistan is not particularly developed, due to the cost of fish, which is higher than the cost of fish grown in the traditional way. For this reason, many entrepreneurs eschew this type of fish farming. However, this method allows you to get from 1 hectare to 100 tons of products, and with the traditional no more than 2 tons.

The economic and climatic conditions of Uzbekistan make it possible to create efficient fish farms. The conditions are created from materials that are not difficult to obtain and are available in the local market at affordable prices. Good food for the fish produced is imported from other foreign countries, but local producers try to produce their own food that is not inferior in quality to foreign ones.

\section{Conclusions}

Cage fish farming has a high productivity of 40-200 kg / m3, compared with traditional fish farming in ponds of Uzbekistan $0.05-0.1 \mathrm{~kg} / \mathrm{m} 3$, this figure is 1000 times higher. In general, the fishing industry can be considered profitable with the production of 20 tons of 
fish per year. In this situation, the fish industry can justify its costs. And the costs consist of capital and working costs [8].

Capital costs include:

- Formation of fish farming and biological justification for the creation of a fish farm;

- Purchase and installation of cages, fish farming equipment;

- Improving coastal infrastructure;

- Purchase of cage maintenance;

- Creation of a feed workshop and so on;

- other expenses.

Working expenses include:

- Fish planting material;

- Feed and feed ingredients;

- Wage fund;

- Transportation costs and electricity;

- Tax;

- other expenses.

Let's consider an example of calculating the creation of a single cage fish farm with a productivity of $40 \mathrm{~kg} / \mathrm{m} 3$. for this purpose, the volume of the cage should be $500 \mathrm{~m} 3$. These cages, made by local producers, cost less than $\$ 3,000$. As we know from the experience of other countries, capital expenditures based on depreciation will have to be reimbursed within 5 years.

Consider the revenue and profit model for growing 20 tons of commercial carp. When producing 20 tons of carp in a family contract, wages are not taken into account, since such a small volume of production is typical for family fish farms without the involvement of hired labor. The cost of approximately calculating all types of costs will be 462 million soums, income 600 million soums, in this scenario, the total profit will be 138 million soums. Based on this, we see that the fish farm of the cage type is a highly profitable enterprise [9].

Despite many positive aspects, cage fish farming also has negative aspects. The main problem is the pollution of the reservoir with organic substances. Such pollution appears when fish are densely planted and intensively fed. To prevent this, the total planting of cages should not exceed $0.1 \%$ of the area of the entire water body.

Do not forget about the marketing side, the main goal of fish farming is to make a profit. A sales system should be developed along with a business plan [10].

Foodservice businesses should remember that they need a year-round supply of fresh fish. The strategy of selling in small batches ( $10 \mathrm{~kg}$ of fish per day) throughout the year is appropriate here. Gardens, unlike the traditional method, are ideal. It is appropriate to plan part of the cages with fish of a commercial size, and fill the main part with smaller fish, which will grow in the following months of selling commercial fish. Many experienced fish farmers own more than two cages, some stocked with small fish, others with larger fish [11].

The sales market must be selected in advance. The marketing strategy of commercial fish depends directly on the amount of fish, transportation and processing capacities and market selection (fig.3).

Do not forget that the practice of cage culture is possible at a certain depth of the reservoir. And there are many other cost-effective ways of intensive fish farming. It is only necessary to select a convenient and appropriate method for the manufacturer.

Do not forget that the practice of cage culture is possible at a certain depth of the reservoir. And there are many other cost-effective ways of intensive fish farming. It is only necessary to select a convenient and appropriate method for the manufacturer [12]. 


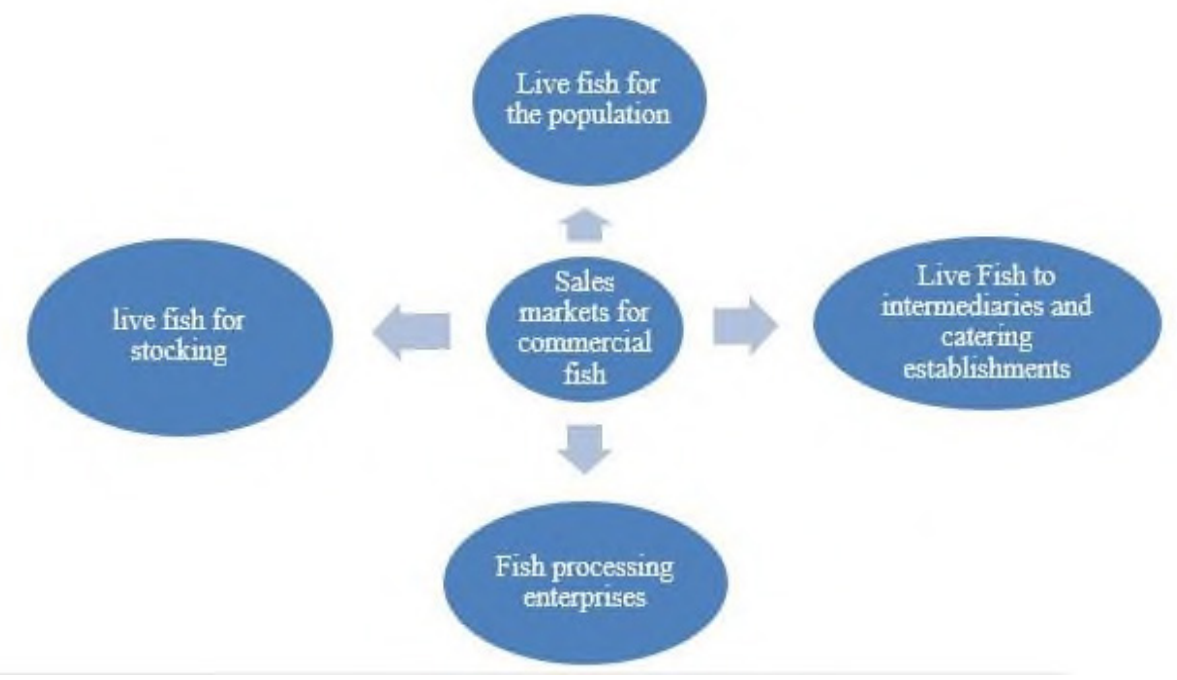

Fig. 3. Sales markets for commercial fish.

Do not forget that the practice of cage culture is possible at a certain depth of the reservoir. And there are many other cost-effective ways of intensive fish farming. It is only necessary to select a convenient and appropriate method for the manufacturer [13].

The head of state Mirziyoyev sh. M. signed a decree aimed at the development of the fishing industry [2]. According to this resolution, a number of changes are being made:

- In artificial reservoirs for fish farms, the tax for the use of water resources is calculated at the rates of irrigation of agricultural land (paying attention to the volume of water taken and returned from the water body);

- Abolition of tax on water resources used from collector and drainage waters [14];

- The amount of water subject to taxation is determined based on the fact that it is used by organizations that are part of the Ministry of Water Resources;

- The list of collector and drainage networks that can be used for fish farms is published and formed by the Ministry of Water Resources [15].

\section{References}

1. B.G. Komilov, R.B. Kurbanov, T.V. Salikhov, Fish farming (Breeding of carp fish in Uzbekistan, Tashkent, 2003)

2. Resolution of the President of the Republic of Uzbekistan "On additional measures for the accelerated development of the fishing industry" (Tashkent city, 2018)

3. Order of the President of the Republic of Uzbekistan "On measures to support and improve the efficiency of the fishing industry" (PP-4816 of 08/29/2020)

4. B.K. Karimov, B.G. Kamilov, M. Upare, R. Van Anrooy, P. Bueno, D.R. Shohimardonov, Aquaculture and inland fisheries in Uzbekistan: review of the current status and conception of development (2008)

5. E.V. Levkina, M.E. Vasilenko, The effectiveness of the fishing industry: theory, methodology and practice, Internet journal "Science" 6 (19) (2013)

6. S.I. Kurdyukov, Methodological aspects of assessing the socio-economic efficiency of the functioning of the fishery complex (Russia, 2012)

7. S.N. Aleksandrov, Cage fish farming (AST, Donetsk: Stalker, 2005) 
8. Yu.L. Gerasimov, Fundamentals of fisheries (Publishing House "Samara University", 2003)

9. F.G. Martyshev, Pond fish farming (Higher school, 1973)

10. U.R. Sangirova, The effectiveness of the development of the fishing industry in Uzbekistan

11. M.C. Beveridg, Cage and pen fish farming: carrying capacity models and environmental impact, Food \& Agriculture Org. 255-259 (1984)

12. R. Goldburg, R. Naylor, Future seascapes, fishing, and fish farming, Frontiers in Ecology and the Environment 3, 1, 21-28 (2005)

13. I.S. Arvanitoyannis, A. Kassaveti, Fish industry waste: treatments, environmental impacts, current and potential uses, International journal of food science \& technology 43, 4, 726-745 (2008)

14. I.V. Andronova, E.A. Yakimovich, World fish market: current trends, state and prospects, Bulletin of the Peoples' Friendship University of Russia. Series: Economics 27, 2, 259-268 (2019) http://dx.doi.org/10.22363/2313-2329-2019-27-2-259-268

15. M. Halwarth, Cage aquaculture: regional reviews and a worldwide review (Rome: FAO, 2010) 